particularly such as are ricb in alkaliae salts, and also acid fruits, are permissible. In all cases, horvever, nside from generalities, individuol idiosyncrasies sbould he noted and the character of the diet arraaged in accordoace therewith As regards internal medieation, arseaic holds first place as to frequency of admiaistration, and is luuded hy Gowers and Weir Mitchell for the treatmentof hahit spasm. Although Oppenheim considers it valueless in Gilles de a Tourette's disease, I believe I have seen good results follow its use. The author last quoted has as little faith in byoscine and eserine, al though after usiug the latter he was ahle to record cessation of movements for several days in one case, but only after iatoxication had taken place. Oae will be compelled to give bromides nt times, hut their constant use canaot be recommeaded. When the digestive tract is in good coadition and the diet full but judicious, the ordinary toaic mistures, sometimes largely prescribed, may be dispensed with. In many cases their employmeat had better be altogetber eliminated, is the customary alcoholic meastruum is hadly borne, as a rule. Even in small quantities it moy derange digestion and affect mental cootrol. Warm boths aod galvanic electricity moy be ndministered for their quietiag effect. The skia should he kept active by means of the former; cold spoages may be given wbere well borne. Some plan of forced nutrition based upoa tbe Weir Mitcbell treatmeot is always indicated, but demands porticulor vigilonce to note that digestion keeps pace with the increased quantities of food consumed. Success io effectiag an iacrease in body-weigbt will be accompanied by a cessation of the inanition tritchings previously mentioned.

Charcot. Quoted by Osler.

\title{
Bimlography.
}

Gowers. Disenses of the Fervous System, 1596.

Giltes de is Tourette.

Guignor. Quoted by Oster, Oppettelm.

Kriepelln. Lehrbuch der Prychistrie, 2895,

Oaler. Practuce of Medicine, 189.

- On Chores and Choralform Afections, 1805.

Oppenheim. Lehrbnch der Nerrenkrankheiten, 1891.

Sachs Nervous nlseases of Chlldren, 1895.

Wood, H. C. American Text-book of tbe Theory and Practuce of siedicine, 1894. :

\section{ANEURISM OF THE CORONARY ARTERY; A REPORT OF TWO CASES.}

\author{
BY JosepH A. CAPPS, A.M., M.D.,

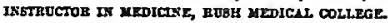

(From the Pathologioal Laboratory of Rush srotical College)

THE specimens here described were both kindly given to the writer by Dr. Ludvig Hektoen, and are reported somewhat in detail on account of the great rarity of tbe conditions. 
Case I.-The suhject, a man aged ahout forty years, was found dead in the street, the nutopsy heing performed hy Dr. L. J. Mitchell. Unfortunately, the hody was never identified and nothing could he lenrned concerning his history.

At the post-mortem exnminntion no evidence of violence was discovered. The brain, alimentrry tract, liver, nnd spleen were normal in appearance. A few pleuritic ndhesions hound down the lungs to the chest wall. The kidneys showed the effects of $n$ slight chronic diffuse nephritis. The chief interest centred in the heart and adjoining vessels. The weight of the henrt is 300 grms. Externally the specimen presents $\mathbf{n}$ rounded eminence, situnted over the left aurjcle, hehind and to the left of the root of the pulmonary artery. Upon lnying open the cavities the mitral, tricuspid, md pulmonary vnlves nre seen to he normnl. The heart muscle is of a nntural color. The semilunar valves nre thin, translucent, not deformed, md close tightly. Near the hase of the norta nnd in the sinuses of Valsalvn the intima is

Fio. 1.

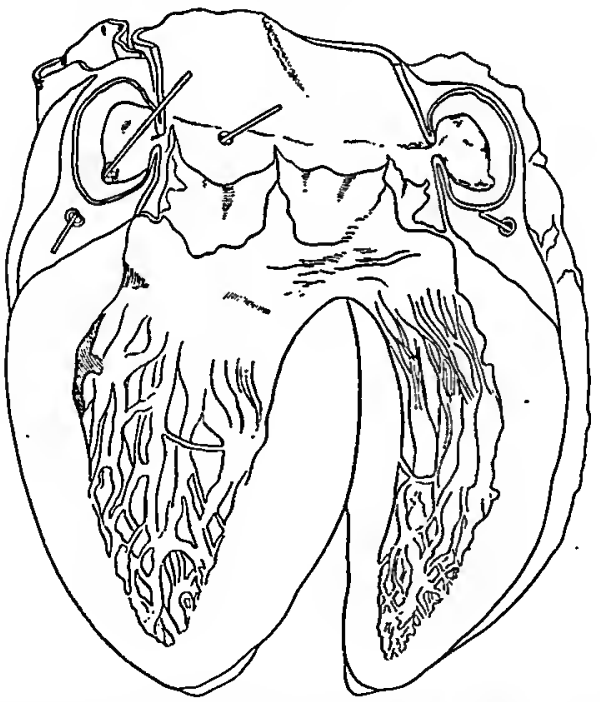

dotted with a few whitish areas where a moderate degree of sclerosis nnd futty degeneration has taken place. These chnnges, however, nre not more mnrked than is usual nt the age of forty-eight. Nowhere is there any deposit of lime snlts. The opening of the left coronary 
artery is ealarged and irregulnr. Section reveals just heyond the orifice a dilatation of the artery wall outward, forward, and dowa ward, forming a tumor the size of a pigeon's egg. This sac is nearly filled with lnmillated hlood-clot, leaviag a eavity ahout as lnrge as a hazel-aut. Arouad the adherent clot the wall of the artery can he traced distinctly. The distal portion of the aneurism commnnicates with the artery heyond. The dilntation extends to the division of the vessel into its two hranches. In the posterior or transverse hranch the wall is sclerotic hut calcified; the nnterior or descending hranch is also thickeaed and its lumea filled with a thromhus. Only slight atheromntous chnnges are present in the right coronary s rtery.

Aficroscopical Examination. Sections of the aneurism were cut parallel to the coronary artery and includiag its origin from the aorta. Imme. diately ahore the orifice the aortic wnll is iafiltrated, the iavasioa of rouad cells apparently starting $n t a$ hreak in the iatima aad encronchjag upon the middle coat. Several small areas of necrotic tissue replace the middle and ianer layers of the aorta at the point of juaction with the coroaary. The thromhus, on the whole, is homogeaeous, hut in some plnces is striated. Liaing the iaaer surface of the sac is a thin, irregular layer of relatively recent blood-clot filled with rouad cells and heginaiag to organize. The arterial wall surroundiag the areurism is somewhat thickened, and ia some places there nre strenks or clusters of infiltrating round cells-evidence of inflammation. A cross section of the descending branch of the left coronury exbibits a sclerosis of the rall and a lumen filled with hlood-clot, wbicb is pnle and stains homogeneously, but is not adberent, and, tberefore, probnhly of postmortern origin. Such a view is confirmed by the absence of interstitial cbaages ia the beart muscle supplied hy this vessel. An iateresting coadition is found in a section from one of the columase carare in tbe left ventricle. In regions the cement spaces uaiting the ends of the muscular fibres are much widened, and more rarely a fibre is itself ruptured, lenving the broken ends rough aad lyiag ia a changed direction. This sepnration and rupture of fibres, knowa respectively as segmeatation and fragmentation, was first ohserved hy Renaut ia 1877. By many suhsequent iavestigators, and particularly hy Hektoen," in an exbnustive study, segmentation has beea found quite constantly in cases of - sudden death. The latter author recorded its presence in every one of ten cases of instantaneous death due to traumntism.

CASE II.-Clinical History. J. H. W., a maa, aged thirty-aiae years, and antive bora, was anlmitted to the Cook County Hospital, October 27,1898 . A telegraph operator hy occupntion, he hnd for a year previous heen employed as aa advertisiag agent. Both mnteranl grandfather and grandmother died of apoplexy; mother of heart disease. He always smoked and chewed tohaceo, and used alcohol to excess. Several years ago he contracted syphilis, aad oue year ago had a paralytic stroke. His last illness hegan four weeks hefore eatraace to the hospital, whea he a oticed aumhness and tiagling in tbe legs and feet, and later over the whole body. Duriag this time he had several convulsions. At the time of ndmission he was hnving general coavulsions of about oae miaute's duration, at iatervnls of five minutes.

Physical Examination. Nutrition good. The pupils were equnl aad reacted. The tongue protruded to the left and was tremulous. There was paralysis of the left facial muscles. Two scars of recent origin were 
noted above the left eye; aleo an old depression. Right radial pulse full aad strong, left weaker. Heart sounds loud and irreguler. Luags uormal. Left arm and leg partinlly paralyzed. Temperature, 99.4\% pulse, 124. Uriae acid, 1032, faiat trace of alhumia, granular casts.

The convulsious recurred several times a day, al ways accompanied by unconsciousness. Subsequently he developed a hroncbopaeumonia, from the immediate effects of which he died, Novemher 5, 1898.

Post-mortem Examination. Body of a rather slender, well-a ourished nnd developed mon. Rigor mortis marked; lividity posteriorly. Mucous membraaes of the upper respiratory parsages showed no lesioa.

The skull and scalp exhibited ao changes externally. Internally the rigbt parietal bone showed some fine erosions, corresponding to a circular ares of adhesions between the pia and the dura mater. In the odhesions was a grayish-yellow layer of granulatioa tissue of ratber soft consistency, flattened and circular in outliae. Arouad this district the cortex was somewhnt softened, hut the remaiader of the brain, as well as the pons, medullo, and cerebellum, was normal. The vessels at the base of the braia showed nodular and irregular yellowish tbickeaings.

The abdominnl, pleural, and pericardial cavities were empty, their lining memhranes smooth.

The spleen presented ao nhnormal appearance. The liver weighed 1400 grms., and cut with normal resistance; it showed some congestion of the centres of the lobules. The parcreas and intestines appeared normal. The kidneys weighed 300 grms. The capsules were adherent in places, and the foetal lohulntions were still present. The cortices were rather wider than normal, the markings distinct, the arteries prominent. The testicles were normal.

Orer the upper lohe of the right lung were a few firm adhesions. The lungs crepitated, excepting the left lower Jobe, which weighed 450 grms, sank in woter, and was hluish in color. On the cut aurface were numerous grayish-red granular areas, varying in size from that of a split pea to 1 or $2 \mathrm{~cm}$. in diameter. The lung tiscue hetween these ereas was collapsed and deep red or hluish-red in color. The remaining parts of the lungs were considerahly congested, and the larger hronchi contained mucopus. The perihroncbinl glands were a ormol.

The heart weighs $550 \mathrm{grms}$. There is morked thickening of the left ventriculnr wall. The tricuspid, pulmonary, and ventral valves appear aormal. The endocardium is smooth, excepting that the free inargin of the aortic valves is rough, thickened, and sclerosed. Just helow the junction of the left and aaterior semilunar valves is a small bulging in the septum, which admits tbe tip of the index finger, nnd is lined witb a dense fibrous tissue. Aateriorly the aneurism and the siaus of Valsalva of the posterior pulmonary valve are sepnrated by oaly a thin portition thot is translucent. The " undefended spnce " situated to the rigbt of this cavity is unaffected. Above the left semilunar valve is a bulging of the aortic wall upword and forward into tbe loose periaortic tissue, so that the artery is undermined. Bordering on this aneurism is the left coronary orifice, wbicb is of aormal size. Immediately beyond the opening, bowever, in a fusiform dilatntion of the arterial woll, large enough to contain a hazel-aut, and extending for the most part posteriorly and to the riglit. Its walls are streaked with yellowisb spots, ond in places calcareous scales can be peeled off. Beyond tbis cavity is a second and smaller dilatation of the right wall. 
The heginning of the aorta is very much thickened, the intima irregularly fissured, nnd similar changes exist throughout the entire thoracic aorta.

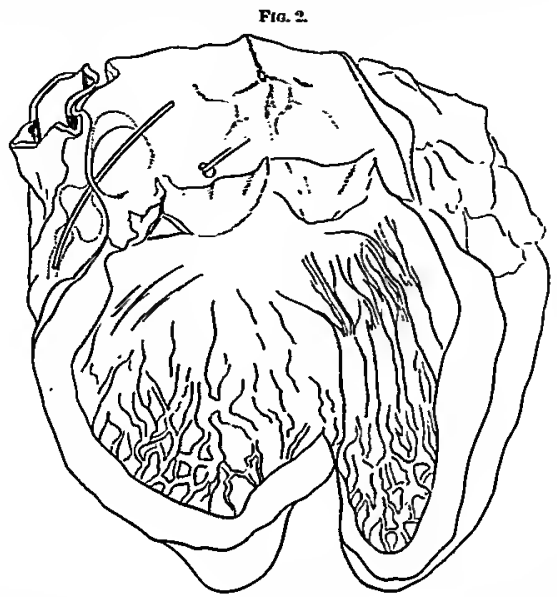

Aricroscopical Examination. In the sections the intimn is secn to he overlaid hy an old thromhus. The artery wnll is thickened. Near the orifice the continuity of the intima is hroken, nnd there has heen nu invasion of round cells. At this point, nnd in other plnces within the aneurism, the inner layer has heen replaced hy calcareous deposits. Some of these calcareous changes extend deep down into the middle coat of the artery.

The heart presents the picture of nn extreme myocnrditis. The hloodreasels are sclerosed and surrounded by dense fihrous tissue. Some of the muscle fihres are ntrophied, some have disappeared, lenving Jarge areas that are occupied hy interstitial cells.

Here, also, as in the previous case, there is n segmentation and fragmentation of the muscle fihres.

I was surprised in reading the literature to lenrn that while aneuristrs of the heart and of the root of the aorta are comparatively common, so very ferv instances of coronary aneurism have been descrihed. The accompnnying tnhle comprises nll the cases that $I$ could find in which the aneurism unquestionahly nrose in the coronary arteries.

Both left and right coronnries seem to be involved ahout nn equal number of times. The usual site of the dilatation is very near the origin from the aorta in the loose cellular tissue, so well descrihed hy 
Vestberg" as the "perisortic space." This location is also a favorite place for interparietal aneurisms of the heart.

The affection vastly predominates in males.

Age bas less influence in the etiology than one would suspect, considering its rôle as a predisposing cauze in aneurism elsewhere. More cases were under forty than over that age. A remarkahle fact is its occurrence in two very young ehildren.

Occupntion is not an important factor, only two subjects being engaged in beavy work. Two individuals gave a history of rheumatism and excessive drinking.

The diagnosis of the lesion was never made during life, since, unless rupture took place, it gave rise to no adventitious sounds, and its location over the auricle did not incresse the area of cardiac dulness.

It is douhtful if uncomplicated, unruptured coronary aneurism has any characteristic symptoms. In two cases dyspnoea, cough, and transient pains over the benrt were present, but could he hetter attributed to coexisting bronchitis and valvular insufficiency of the benrt.

The disense usually terminates in deatb from rupture of the aneurism into the pericardium, eleven of the nineteen cases dying from this complication. In the others the aneurism was apparently henign, and was accidentally discovered at autopsy.

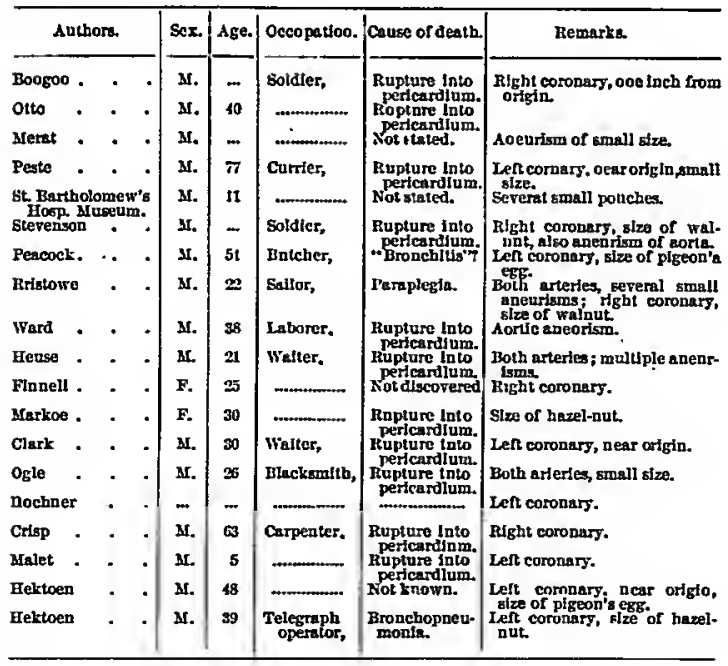




\section{Bibliograyey.}

1. Rensut, Socjcte de Blologic, Jals 7, 1877.

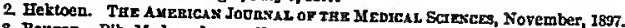

3. Bongon. Bib. Mled, vol $2 x \times$ ril. 1B12

4. Otto. Comp. of Comper. Aratomy, n. aig.

5. Mrerat Dict de ScL Med., 1840, tom. 7. p. 484.

6. Peste. Arehiv. Gétu. de Mled., IBt3, tom. II. p. 274 .

7. St. Bartholomew's Hospltal Mlusenm; citod by Crisp. Loc. clt

8. Stevenson. Chatham Mra Catalogue, p. 33 . Clied b5 Crisp.

9. Peacock. Traus. Path. Soc. of Loudon, 1877, vol. L p. .29.

10. Bristowe. Itd., 1853, vol. ㄱl., p. IS.

11. Ward. Ibld., 1854, vol, vili. p. 1H.

12 Heuse. Bull. de I'Acad. ray. de Belgique, 1856, tom. Xv. p. 492

18. Finneil. New York SPod. Jonm, 1856, rol. xri. p. 82 .

14. Jarkoe. New York Joura. Med. 5cL, 1850, vol. stil, p. 38 .

15. clark. Mid.

16. Ogie. St George'a Hospital Reports, 1867, vol. II p. 285 ,

17. Buchuer. Aneurgim du art, coron, candis, Amsteniam, 18G7.

18. Crisp. Trans. Path. Soc. Lood., 1871, voL, Iril. p. 106.

19. Mrelet. London Lancet, 185T, rol. If. p. $\sigma$.

30. Vestberg. Nond, Mfed. Art., 1897, B. vil., No. 25, C. R.

)

\section{A CRITICAL SUMMARY OF RECENT LITERATURE}

\section{CoNCEnamo}

\section{THE MIOSQUTTO AS AN AGENT IN THE TRANSMISSION OF MLALARIA.}

By Thomas B. Futcher, M.B.,

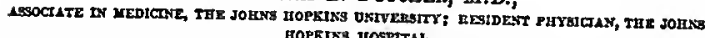
HOPEINS JOSPTIL.

Previous to the year 1898 little was known concerning the means of transmizsion of malarin from one individual to another. This subject had occupied the nttention of mnny ohservers who had devoted much time to the study of the disease. Inoculntion experiments hnd positively proved that malnrin could he transmitted from one individual to another hy the suhcutaneous injection of hlood containing living malarial parasites, hut there was little evidence pointing to the ordinary modes of transmission of the disense that could he regarded as at nll convincing. We were utterly ignorant of the form in which the malarial parasite existed outside the hody, nnd equally in the dark as to the manner in which it entered. The theories advanced were purely hypothetical, and without experimental foundation on which to hase them.

The results of experimental work puhlished during the past year have done much toward dispelling the mist that has so long obscured this important prohlem. The work of Surgeon-Major Ronald Russ, of 
the Indian Medienl Service, concerning the cultivation of the proteosoma labbé (one of the malarial parasites of avian hlood) in gray mosquitoes, afforded the first convincing evidence that the mosquito was prohahly one agent hy means of which mnlarin could he conveyed from bird to hird, and possihly from man to man. The mosquito theory of the transmission of malaria is not a new one. It wns first advanced many decades ago, hut was first vigorously supported hy Manson, from whom Ross received his inspiration to carry out the investigations which have yielded such hrilliant results. As early as 1894, Manson' suggested that the mosquito might he the intermedatie host for the extra-corporenl form of the malarial purasite, just as it is the intermediate host of the filaria nocturna, and that the manner of propagation of the two diseases was analogous. After enumerating several features in which the filarin uocturnn and the malarial parasite resemhle ench ol her, Manson, at that early date, expressed himself as follows: "The parallel is very complete; the conditions, the requirements, and the problem to he solved are apparently identical for hoth parasites. As the prohlem and conditions are the same for hoth organisms the solution of the prohlem may also he the same for hoth. If this he the case, the mosquito having been shown to be the ngent hy which the filaria is removed from the human hloodvessels, this, or a similar suctorial iasect, must he the agent which removes from the human hloodvessels those forms of the malarial organism which are destined to coatiaue the existence of this organiam outside the hody. It must, therefore, be in this or in a similar suctorial insect or insects that the first stages of the extra-corporeal life of the malarial organism are passed." He believed that the flagellated body was the first extra-corporeal stage of the mnlarial parasite. He suggested that the flagella, on hreaking awry from the residual hody or pigmeat-contrining sphere, then, hy virtue of their vibratory movement, penetrate the cells of some organ of the insect.

In 1896, Mranson, in his Goulstonian lectures, ${ }^{3}$ laid especial emphasis on the part which he helieved the flagellnte organisms played iu the propagation of the parasite outside the hody. He held that the crescentic hody of astivo-autamnal malaria and the tertian and quartan spherical hodies which proceed to flagellation were the " extra-corporenl sporulating homologues of the intra-corporeal spore; that the flagellum is the extra-corporeal homologue of the intra-corporeal spore." Both types of sporulating plasmodium were helieved to have corresponding functions, hoth nrising from the same source; one is the germ of the plasmodium inside the human hody; the other is the germ of the plasmodium outside the human hody; hoth function in the propagation of the parasite.

Laveran and Manneberg had also regarded the mosquito theory with favor, hut had not associated the flagellum with the question of the 